Drazic, N., Rakascan, N., Radojevic, V., Popovic, V., Ignjatov, M., Popovic, D., Ikanovic, J., Petkovic, Z. (2021): Cereals as energy sources in the function of circular economy. Agriculture and Forestry, 67 (3): 7-18

DOI: 10.17707/AgricultForest.67.3.01

\begin{abstract}
Nikola DRAZIC ${ }^{1}$, Nikola RAKASCAN ${ }^{1}$, Vuk RADOJEVIC ${ }^{2 *}$, Vera POPOVIC ${ }^{2}$, Maja IGNJATOV ${ }^{2}$, Dragana POPOVIC ${ }^{4}$, Jela IKANOVIC ${ }^{3}$, Zdravka PETKOVIC ${ }^{5}$
\end{abstract}

\title{
CEREALS AS ENERGY SOURCES IN THE FUNCTION OF CIRCULAR ECONOMY
}

\section{SUMMARY}

The circular economy is an approach that integrates the economy, the waste management system and protects the environment. The goal of the circular economy is to optimize the existing system and increase welfare. The growth trend of alternative fuels is evident in the world from year to year, thanks to the development of new technologies for processing biological waste into energy sources. Commercial production needs to be economically and environmentally friendly so that biofuels from renewable sources are an adequate substitute for fossil fuels. In this study, two winter grains, wheat and rye, were examined, during 2018/2019 and 2019/2020, in order to obtain biogas from plant biomass. The results showed that wheat had a statistically significantly higher production of biomass and biogas compared to rye. Based on the analysis of variance, it can be concluded that there are highly significant differences in biomass yield in regard to the genotype $\left(\mathrm{F}_{\text {exp }}=937.75^{* * *}\right)$ and years $\left(\mathrm{F}_{\text {exp }}=28.07^{* * *}\right)$ of investigation. There is a strong positive correlation between biomass and biogas yields.

Keywords: wheat and rye, biomass, biofuels, correlations, economic and environmental profitability

\section{INTRODUCTION}

Wheat (Triticum vulgare L.) and rye (Secale cereale L.) are species that represent one of the most important and earliest domesticated grains in the Old World (Glamočlija et al., 2015). Wheat was grown in the world in 2019 on $216,000,000 \mathrm{ha}$, with an average grain yield of $3.55 \mathrm{t} \mathrm{ha}^{-1}$ and a total production of 766,000,000 t, and rye on 4,213,392 ha with average grain yields $3.04 \mathrm{t} \mathrm{ha}^{-1}$ and with production of 12.801.441 $\mathrm{t}$ (Faostat, 2021). On the territory of the

\footnotetext{
${ }^{1}$ Nikola Drazic, Nikola Rakascan, University of Singidunum, Belgrade, SERBIA

${ }^{2}$ Vuk Radojevic, Vera Popovic, Maja Ignjatov, (corresponding author: vuk.radojevic@ifvens.ns.ac.rs; vera.popovic@ifvcns.ns.ac.rs), Institute of Field and Vegetable Crops, National Institute of the Republic of Serbia, Maksima Gorkog 30, Novi Sad, SERBIA

${ }^{3}$ Jela Ikanovic, University of Belgrade, Faculty of Agriculture, Zemun, SERBIA

${ }^{4}$ Dragana Popovic, University of Novi Sad, Faculty of Economics, Novi Sad, SERBIA

${ }^{5}$ Zdravka Petkovic, University of Belgrade, Faculty of Organizational Sciences (FOS), Belgrade, SERBIA.

Notes: The authors declare that they have no conflicts of interest. Authorship Form signed online. 
Republic of Serbia, wheat is grown on an area of about 600,000 ha, with an average yield of $4.4 \mathrm{t} \mathrm{ha}^{-1}$ and production of $2,535.00 \mathrm{t}$, while rye is grown on average on an area of about 6,000 ha with an average yield of $2.6 \mathrm{t} \mathrm{ha}^{-1}$ and production of $13.000 \mathrm{t}$ (RZS, 2021). The circular economy represents a new approach that integrates the economy and the waste management system, opens up innovative and more efficient ways of production with global efforts for sustainable development. The circular economy model is in stark contrast to the dominant linear economy that promotes the concept of production called "take (from nature), make (in the production process), use and discard (waste)." The circular economy promotes competitiveness, innovation, protects living environment and at the same time contributes to economic growth. It is based on several principles: that products be designed to be reusable after use, and that the energy used in production comes from renewable sources, all with the aim of reducing dependence on resources. Thanks to the development of new technologies for processing bio-waste into energy, the growth rate of the use of alternative fuels is growing significantly (Popovic et al., 2020a; 2020b; 2020c; Ikanovic et al., 2020; Milanovic et al., 2020; Rakascan et al., 2021). According to estimates by energy experts, in highly developed countries it is about $15 \%$ per year. Rakascan et al. (2019a) point out that the cultivation of energy crops helps the development of rural areas (production of raw materials), but also industrial production, which provides the possibility of greater employment in primary crop production and biofuel production. The term biogas means gas produced in anaerobic fermenters and controlled conditions, i.e. in biogas plants. A mixture of gases, whose volume consists of about two thirds of methane and one third of carbon dioxide, is called biogas. By aerobic fermentation, organic biomass is decomposed to carbon dioxide, while methane is obtained by anaerobic means. Methane is a fuel gas, and the goal is precisely its production and use as an energy source (Glamoclija et al. 2015; Popovic et al., 2020b).

Straw, as an agricultural by-product, represents dry grain stalks, after the separation of grain and chaff, and makes up half of the grain yield. After harvest, straw is often burned in the fields. This is the most irrational way of using straw because burning burns all the organic substance that the useful soil fauna would decompose into forms that future crops can use for their needs. Straw burning should be decided only if the wheat was infected with the pathogenic fungus Fusarium sp. and Erysiphe sp. (Glamoclija et al. 2015). In the case of true cereal varieties, which have lower stalks and are less pruned, the share of harvest residues in the total yield is $40-50 \%$. With a grain yield of $5,000 \mathrm{~kg} \mathrm{ha}^{-1}, 3,500-$ $4,500 \mathrm{~kg} \mathrm{ha}^{-1}$ straw can be obtained. According to the results of the research, which are stated by British authors, if the straw of cereals, grown only in the area of the eastern part of the Midlands, were used to obtain biofuels, the amount of obtained energy would cover about $1.5 \%$ of British consumption. However, the views of local farmers are explicit, and they insist that these secondary products be returned to the land by plowing or as manure, which has a far greater importance on soil fertility and further plant production. Finding the optimal 
solution for the use of cereal straw should be the subject of further research, as Copeland and Turley (2008) point out. Straw can also be used to obtain liquid biofuels (ethanol) because it has large amounts of carbohydrates. Today, in addition to the requirements for fuel quality, there are increasing requirements for low exhaust emissions of toxic gases and obtaining fuel from renewable energy sources.

The aim is to produce new fuels on new technologies that offer significant potential in improving air quality and reducing gas emissions, all with the aim of protecting the environment and the impact on global climate change. However, the complete penetration of new technologies on the market is a long process, and some of the new technologies are still in the development phase and require significant investments until final application (Lakic et al., 2018; Ikanovic et al., 2018; Jankovic et al., 2017; 2019). The situation is similar in the field of fuel application technologies. All these circumstances force the world factors in the automotive industry and energy in general, to develop new types of fuels from renewable sources from biomass of agriculture and agricultural crops.

In the fight against current problems, last year, within the $21^{\text {st }}$ conference on climate change held in Paris, a new global agreement was adopted, which has a much more ambitious plan than the previous one. 196 member states, including the Republic of Serbia, have committed themselves to the obligatory reduction of greenhouse gases, and the allowed rise in temperature to $1.5^{\circ} \mathrm{C}$ starting in 2020 . The obligation of our country is to reduce emissions by $9.8 \%$ by 2030 compared to 1990. As an economically much weaker country, compared to developed European countries, Serbia lags far behind in terms of production and application of clean energy, although it cannot be disputed the fact that we have natural resources that should be used for the purpose of obtaining energy as they point out (Jankovic et al., 2017). The essence of converting harvest and all other plant residues into biofuels is not only obtaining as much energy as possible, but also applying a sustainable method of production from which everyone will benefit.

The aim of this study was to examine the possibility of using wheat and rye biomass as an energy source in the process of obtaining biogas.

\section{MATERIAL AND METHODS}

\section{Experimental design}

During 2018/2019 and 2019/2020, a field micro-survey was set up according to a random block system in 10 repetitions with the size of the basic plots of $10 \mathrm{~m}^{2}\left(5 \mathrm{~m} \mathrm{x} 2 \mathrm{~m}\right.$ ) in Dolovo ( $44^{\circ} 54^{\prime} \mathrm{N}, 20^{\circ} 52^{\prime} \mathrm{E}, 101 \mathrm{~m}$ a. s. 1.) near Pancevo, on chernozem type land. The subject of the research were two winter cereals: wheat, variety Ilina (created at the Field and Vegetable Crops, Novi Sad) and rye, variety Tayo (KWS) and the examined parameters are productivity parameters: biomass yield and biogas yield. During the vegetation season, standard technological practices for growing winter cereals were applied. For the analysis of productive traits, samples were taken from the cut biomass at the stage of technological maturity. The technology of obtaining biogas from biomass was 
performed in a biodigester, where the biomass was previously ground and inserted into a biodigester where fermentation and biogas production are performed. Since its inception Biogas Energy (company) has been involved in research into the possibilities of improving the supply of biomass for its needs in an environmentally, economically and energy sustainable way. Biogas yield was determined by analysis of wheat and rye silage in the laboratory of the Technical Faculty in Novi Sad and calculated on cubic meters per ton.

\section{Statistical analysis}

The analysis of the obtained experimental data was performed through analytical statistics with the help of the statistical package STATISTICA 12 for Windows (StatSoft). The obtained results are shown in the table. The significance of differences in mean values of the treatments was tested by the LSD test. Relative dependence was defined through correlation analysis (Pearson's correlation coefficient), and the coefficients that were obtained were tested at the $5 \%$ and $1 \%$ levels of significance.

\section{Meteorological conditions}

Climatic parameters were obtained from the meteorological station in Pancevo the average monthly temperatures during the research years. City Pancevo is located in the Autonomous Province of Vojvodina, in the Republic of Serbia on the banks of rivers Tamis and Danube, in the southern part of Banat in a fertile valley at an altitude of $77 \mathrm{~m}\left(44^{\circ} 54^{\prime} 02^{\prime \prime} \mathrm{N} ; 20^{\circ} 52^{\prime} 23^{\prime \prime} \mathrm{E}, 101 \mathrm{~m}\right.$ asl). The South Banat administrative district extends in the northern part of Serbia, ie in the south-eastern part of the northern Serbian province, Vojvodina, (Pictures $1 \mathrm{a}, 1 \mathrm{~b})$ at $4,245 \mathrm{~km}^{2}$.

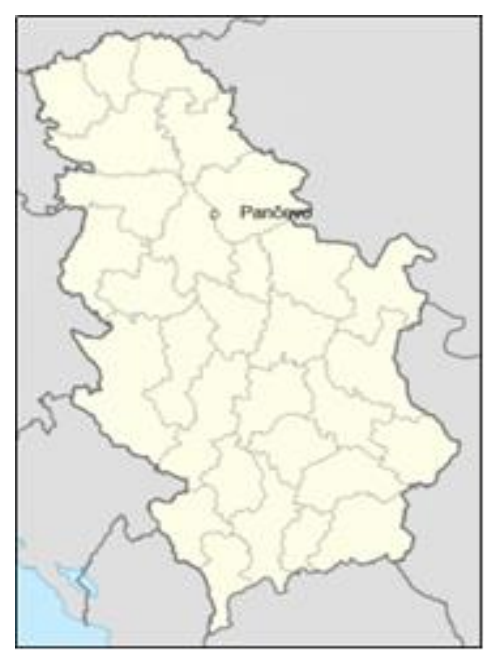

a.

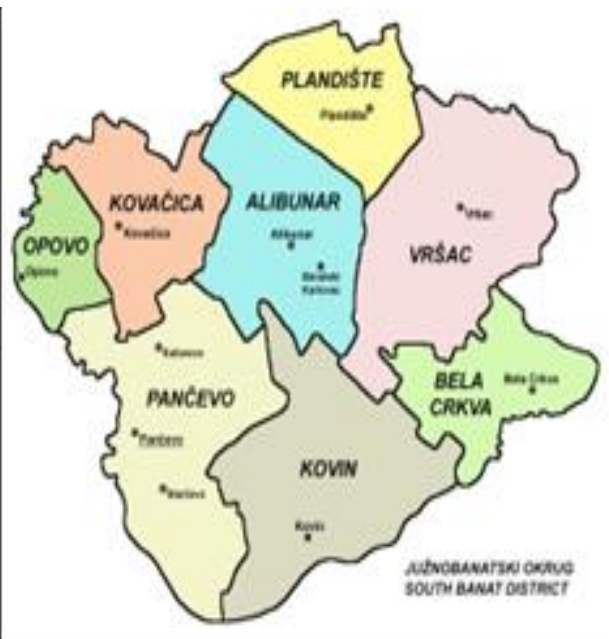

b.

Picture 1. City Pancevo in Serbia (a) and Pancevo in South Banat District (b). 
Agricultural land accounts for 80.9\%. Pancevo located 18 kilometers northeast of Belgrade. Pancevo is characterized by a temperate-continental climate, with an average perennial temperature of $11.3^{\circ} \mathrm{C}$ and precipitation 643 $\mathrm{mm}$. Favorable conditions in the vegetation period have influenced the fact that a large part of the population is engaged in agriculture.

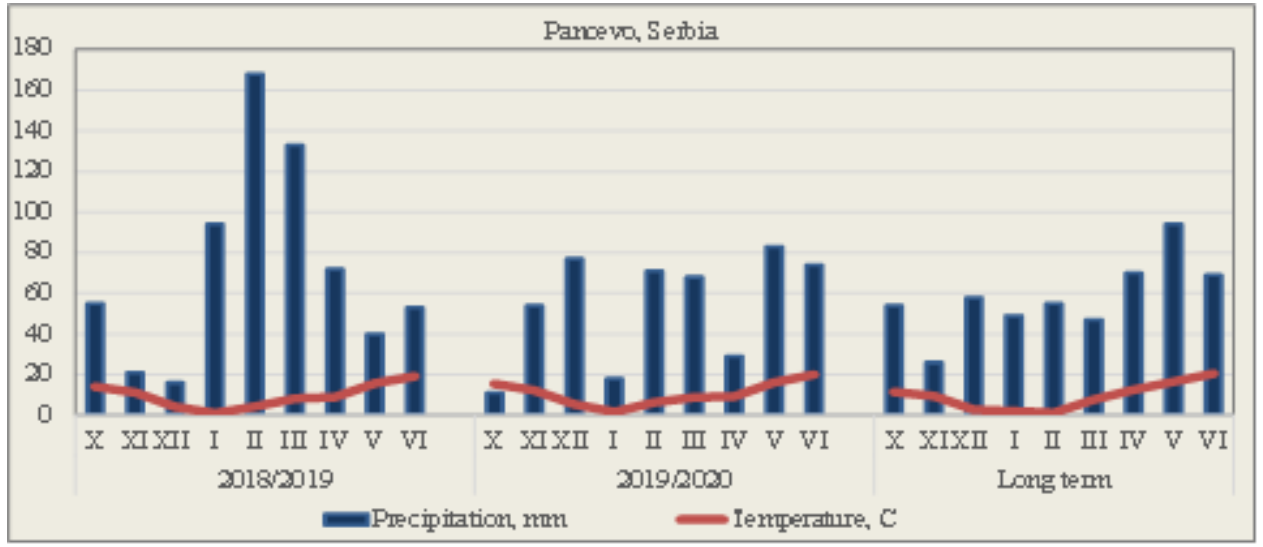

Figure 1. Precipitation and temperatures for the vegetation period of winter wheat and rye, Pančevo, Serbia

The amount of precipitation by months for the vegetation period of winter wheat in the years of testing, as well as the multi-year average (2010-2020) are shown in Graph 1. Mean multi-year temperatures for the vegetation period were $10.07{ }^{\circ} \mathrm{C}$ while the total vegetation precipitation was $522 \mathrm{~mm}$. In the examined period, the average vegetation temperatures varied from $9.64{ }^{\circ} \mathrm{C}(2018 / 2019)$ to $10.5^{\circ} \mathrm{C}(2019 / 2020)$ while the total vegetation precipitation varied from $485 \mathrm{~mm}$ (2019/2020) to $652 \mathrm{~mm}(2018 / 2019)$, (Figure 1).

Climate has a great influence on the growth and development of plants, so the elements of climate (light, heat, air and water) very often appear as a limiting factor (Popovic et al., 2012; 2020b; 2020c; Ljubicic et al., 2021). Significantly higher total precipitation for the vegetation period of winter cereals was in the first year of testing of $652 \mathrm{~mm}$ was higher compared to the precipitation for the multi-year average for the area of Pancevo by $130 \mathrm{~mm}$ while temperatures were lower by $0.33^{\circ} \mathrm{C}$.

\section{Yield of wheat and rye biomass}

Based on the analysis of variance, it can be concluded that there are highly significant differences in biomass yield in regard to the genotype $\left(\mathrm{F}_{\exp }=937.75^{* * *}\right)$ and years $\left(\mathrm{F}_{\mathrm{exp}}=28.07^{* * *}\right)$ of investigation, Table 1 .

The interaction of the investigated factors ( $\mathrm{Y} \times \mathrm{G})$ exhibits was significant affect in all cereals biomass yield $\left(\mathrm{F}_{\mathrm{exp}}=9.88^{*}\right),(\mathrm{p}>0.05)$. (Table 1). The present results confirm the opinion of many authors that the traits analysed are genetically determined but are strongly modified by the environment and weather conditions (Popovic et al., 2020c; Rajicic et al., 2020a; 2020b). 
Wheat had a statistically significantly higher average biomass yield compared to rye, $p \geq 05$. The average biomass yield of the Ilina wheat variety was $2.79 \mathrm{t} \mathrm{ha}^{-1}$, while the rye yield was $2.22 \mathrm{t} \mathrm{ha}^{-1}$. Statistically significantly higher yield was achieved in the second year of the study 2019/2020 $\left(2.56 \mathrm{t} \mathrm{ha}^{-1}\right)$ compared to the first year, 2018/2019 $\left(2.46 \mathrm{t} \mathrm{ha}^{-1}\right)$, Table 2, Figure 2.

Table 1 . The analysis of variance for the cereals biomass yield

\begin{tabular}{|lrrrrr|}
\hline \multicolumn{1}{|c}{ Effect } & Df & \multicolumn{1}{c}{ SS } & \multicolumn{1}{c|}{ MS } & \multicolumn{1}{c|}{ F } & p-level \\
\hline Intercept & 1 & 75.350 & 75.350 & $72919.70^{* * *}$ & 0.000 \\
Genotype & 1 & 0.969 & 0.969 & $937.75^{* *}$ & 0.000 \\
Year & 1 & 0.029 & 0.029 & $28.07^{* *}$ & 0.000 \\
Year x Genotype (YxG) & 1 & 0.010 & 0.010 & $9.88^{* *}$ & 0.014 \\
Error & 8 & 0.008 & 0.001 & & \\
\hline
\end{tabular}

significant at $0.05 ;{ }^{* *}$ significant at 0.01 ;

Table 2. Descriptive Statistics of wheat and rye biomass yield, 2018/19-2019/20

\begin{tabular}{|c|c|c|c|c|c|c|c|c|}
\hline Parameters & \multicolumn{2}{|c|}{ Level of Factor } & No & $\begin{array}{c}\text { Biomass } \\
\text { yield } \\
\text { Mean }\end{array}$ & $\begin{array}{c}\text { Biomass } \\
\text { yield } \\
\text { Std.Dev. }\end{array}$ & $\begin{array}{l}\text { Biomass } \\
\text { yield } \\
\text { Std.Err }\end{array}$ & $\begin{array}{c}\text { Biomass } \\
\text { yield } \\
\mathbf{- 9 5 , 0 0 \%}\end{array}$ & $\begin{array}{c}\text { Biomass } \\
\text { yield } \\
+\mathbf{9 5 , 0 0 \%}\end{array}$ \\
\hline Total & & & 12 & 2,5058 & 0,3039 & 0,0877 & 2,3126 & 2,6989 \\
\hline Genotype;G & Wheat & & 6 & 2,7900 & 0,0357 & 0,0146 & 2,7524 & 2,8275 \\
\hline $\begin{array}{c}\text { Genotype, } \\
\text { G }\end{array}$ & Ray & & 6 & 2,2216 & 0,0906 & 0,0370 & 2,1265 & 2,3167 \\
\hline Year, Y & $\begin{array}{l}2018- \\
2019\end{array}$ & & 6 & 2,4566 & 0,3455 & 0,1410 & 2,0940 & 2,8192 \\
\hline Year, Y & $\begin{array}{l}2019- \\
2020\end{array}$ & & 6 & 2,5550 & 0,2794 & 0,1140 & 2,2617 & 2,8482 \\
\hline$G \times Y$ & Wheat & $\begin{array}{l}2018- \\
2019\end{array}$ & 3 & 2,7700 & 0,0435 & 0,0251 & 2,6617 & 2,8782 \\
\hline Gx Y & Wheat & $\begin{array}{l}2019- \\
2020\end{array}$ & 3 & 2,8100 & 0,0100 & 0,0057 & 2,7851 & 2,8348 \\
\hline$G \times Y$ & Ray & $\begin{array}{l}2018- \\
2019\end{array}$ & 3 & 2,1433 & 0,0450 & 0,0260 & 2,0313 & 2,2553 \\
\hline$G \times Y$ & Ray & $\begin{array}{l}2019- \\
2020\end{array}$ & 3 & 2,3000 & 0,0100 & 0,0057 & 2,2751 & 2,3248 \\
\hline
\end{tabular}

\begin{tabular}{|c|c|c|c|}
\hline \multirow{2}{*}{ LSD } & \multicolumn{3}{|c|}{ Biomass yield } \\
\cline { 2 - 4 } & G & Y & G x Y \\
\hline 0.05 & 0.043 & 0.043 & 0.061 \\
\hline 0.01 & 0.062 & 0.062 & 0.088 \\
\hline
\end{tabular}

The interaction of the examined factors had a statistically significant influence on the yield of wheat and rye biomass. Average rye biomass yields were $2.14 \mathrm{t} \mathrm{ha}^{-1}(2018 / 2019)$ and $2.30 \mathrm{ha}^{-1}(2019 / 2020)$ and were significantly lower than wheat biomass yields in 2018/2019 $\left(2.77 \mathrm{t} \mathrm{ha}^{-1}\right)$ and in 2019/2020 $\left(2.81 \mathrm{t} \mathrm{ha}^{-1}\right)$, Table 2, Figure 2. 


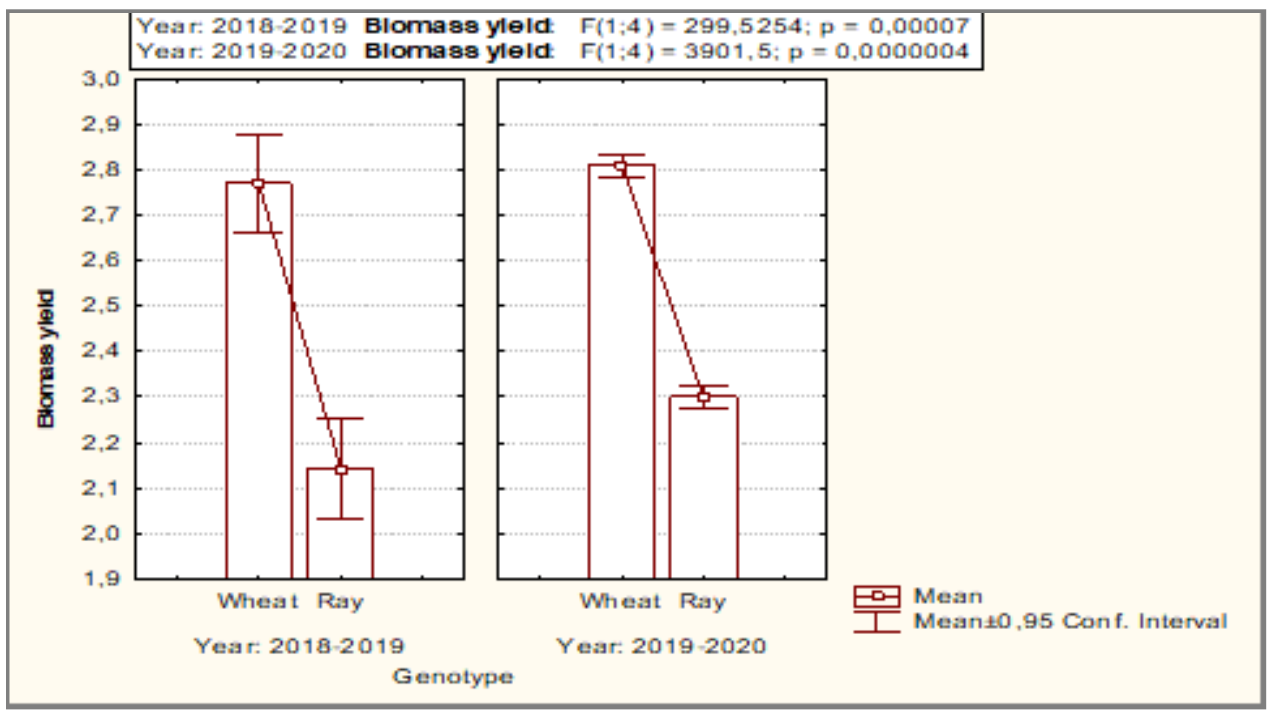

Figure 2. Wheat and rye biomass yield, Pancevo, 2018/2019-2019/2020

\section{Biogass yield of wheat and ray}

Based on the analysis of variance, it can be concluded that there are highly significant differences in biogas yield in regard to the genotype $\left(\mathrm{F}_{\text {exp }}=3902.25^{* *}\right)$ and investigated years $\left(\mathrm{F}_{\exp }=5.32^{*}\right)$. The interaction of the investigated factors ( $\mathrm{Y}$ $x \mathrm{G})$ exhibits was no significant affect in yield ( $\mathrm{p}>0.05)$, Table 3 .

Table 3. The analysis of variance for the wheat and ray biogas yield

\begin{tabular}{|lrrrrr|}
\hline \multicolumn{1}{r}{ Effect } & Df & \multicolumn{1}{c}{ SS } & \multicolumn{1}{c}{ MS } & \multicolumn{1}{c|}{ F } & p-level \\
\hline Intercept & 1 & 102260 & 102260 & $56125.91^{* *}$ & 0.000 \\
Genotype, G & 1 & 71098 & 71098 & $3902.25^{* *}$ & 0.000 \\
Year, Y & 1 & 97 & 97 & $5.32^{*}$ & 0.005 \\
Y x G & 1 & 79 & 79 & $4.35^{\text {ns }}$ & 0.070 \\
Error & 8 & 146 & 18 & & \\
\hline
\end{tabular}

${ }^{\mathrm{ns}}$ non significant; ${ }^{*}$ significant at $0.05 ;{ }^{* *}$ significant at 0.01 ;

The present results confirm the opinion of many authors that the traits analysed are genetically determined but are strongly modified by the environment and weather conditions (Popovic et al., 2020c; Rakascan et al., 2021).

Wheat had a statistically significantly higher average biogas yield compared to rye, $\mathrm{p} \leq 05$. The average biogas yield of the Ilina wheat variety was $368.89 \mathrm{~m}^{3} \mathrm{t}^{-1}$ while the rye yield was $214.94 \mathrm{~m}^{3} \mathrm{t}^{-1}$. Higher biogas yield was achieved in the second year of the 2019/2020 $\left(294.76 \mathrm{~m}^{3} \mathrm{t}^{-1}\right)$ compared to the first year, $2018 / 2019\left(289.08 \mathrm{~m}^{3} \mathrm{t}^{-1}\right)$ but the difference was not significant. The interaction of the examined factors did not have a statistically significant effect on the yield of wheat and rye biogas, Table 4, Figure 3. 


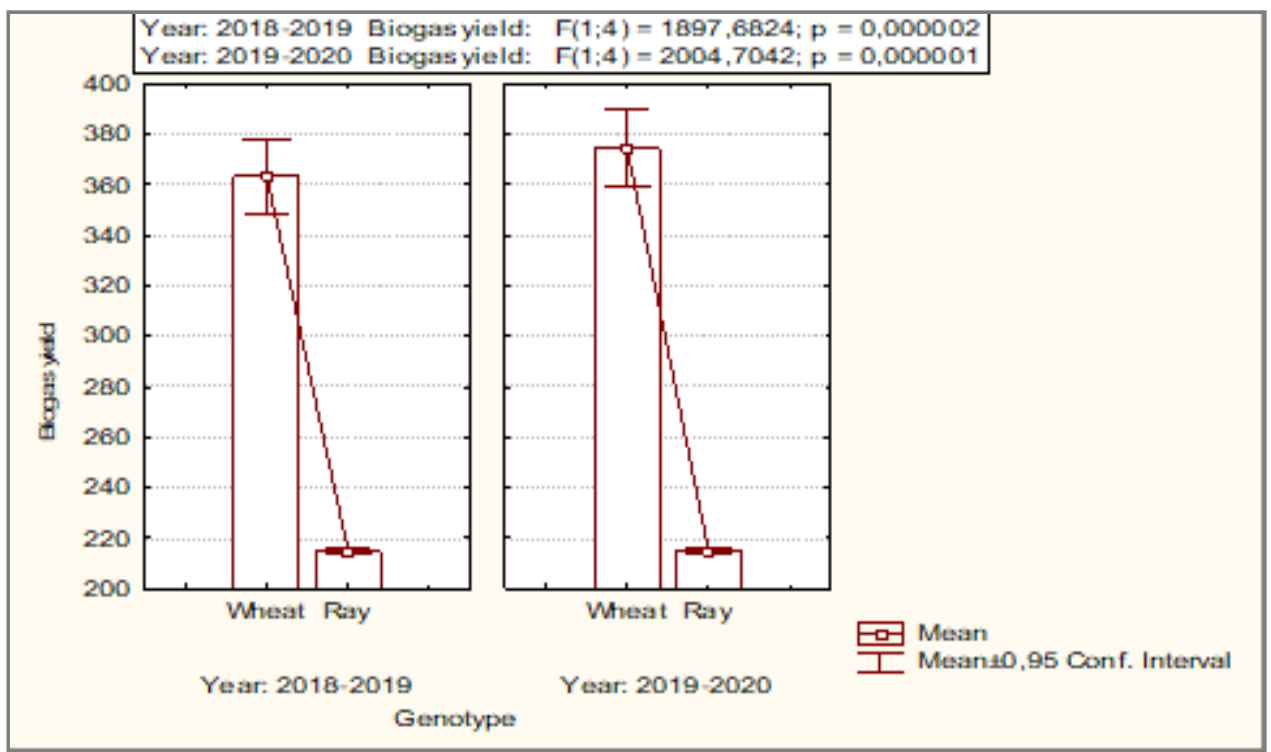

Figure 3. Wheat and rye biogas yield, Pancevo, 2018/2019-2019/2020

Table 4. Descriptive Statistics of wheat and rye biogas yield

\begin{tabular}{|l|l|l|l|l|l|l|l|l|}
\hline Parameters & \multicolumn{2}{|l|}{ Level of Factor } & No & $\begin{array}{l}\text { Biogas } \\
\text { yield } \\
\text { Mean }\end{array}$ & $\begin{array}{l}\text { Biogas } \\
\text { yield } \\
\text { Std.De } \\
\text { v. }\end{array}$ & $\begin{array}{l}\text { Biogas } \\
\text { yield } \\
\text { Std.Err }\end{array}$ & $\begin{array}{l}\text { Biogas } \\
\text { yield } \\
\mathbf{- 9 5 , 0 0 \%}\end{array}$ & $\begin{array}{l}\text { Biogas } \\
\text { yield } \\
\mathbf{+ 9 5 , 0 0 \%}\end{array}$ \\
\hline Total & & & 12 & 291,919 & 80,577 & 23,260 & 240,723 & 343,116 \\
\hline Genotype, G & Wheat & & 6 & 368,892 & 8,013 & 3,271 & 360,483 & 377,301 \\
\hline Genotype, G & Ray & & 6 & 214,946 & 0,438 & 0,179 & 214,486 & 215,407 \\
\hline Year, Y & $\begin{array}{l}2018- \\
2019\end{array}$ & & 6 & 289,078 & 81,588 & 33,308 & 203,456 & 374,700 \\
\hline Year, Y & $\begin{array}{l}2019- \\
2020\end{array}$ & & 6 & 294,761 & 87,223 & 35,608 & 203,225 & 386,296 \\
\hline G x Y & Wheat & $2018-$ & 3 & 363,480 & 5,906 & 3,410 & 348,806 & 378,153 \\
\hline G x Y & Wheat & $\begin{array}{l}2019 \\
2020\end{array}$ & 3 & 374,305 & 6,142 & 3,546 & 359,047 & 389,563 \\
\hline G x Y & Ray & $\begin{array}{l}2018- \\
2019\end{array}$ & 3 & 214,676 & 0,339 & 0,195 & 213,833 & 215,519 \\
\hline G x Y & Ray & $\begin{array}{l}2019- \\
2020\end{array}$ & 3 & 215,216 & 0,383 & 0,222 & 214,262 & 216,170 \\
\hline
\end{tabular}

\begin{tabular}{|l|l|l|l|}
\hline \multirow{2}{*}{ LD } & \multicolumn{3}{|c|}{ Biogas yield } \\
\cline { 2 - 4 } & G & Y & G x Y \\
\hline 0.05 & 5.681 & 5.681 & 8.037 \\
\hline 0.01 & 8.267 & 8.267 & 11.693 \\
\hline
\end{tabular}




\section{Correlations between tested parameters}

The relationship between biomass yield and biogas properties in rye and wheat was presented using correlation analysis, using the Pearson linear correlation coefficient. A strong positive correlation between biomass and biogas yields was calculated $\left(\mathrm{r}=0.98^{* *}\right)$, table 5 .

Table 5. Correlations beetwen tested parameters

\begin{tabular}{|l|c|c|c|c|}
\hline Parameter & $\begin{array}{c}\text { Biomass } \\
\text { yield }\end{array}$ & $\begin{array}{c}\text { Biogas } \\
\text { yield }\end{array}$ & Temperature & Precipitation \\
\hline Biomass yield & 1.00 & $0.98^{* *}$ & $0.17^{\mathrm{ns}}$ & $0.17^{\mathrm{ns}}$ \\
\hline Biogas yield & $0.98^{* *}$ & 1.00 & $0.04^{\mathrm{ns}}$ & $0.04^{\mathrm{ns}}$ \\
\hline
\end{tabular}

${ }^{\text {ns }}$ non significant; ${ }^{* *}$ significant at 0.01 .

The use of correlation coefficient analysis in the wheat and rye, simplify dependable classification of bread wheat and rye, the identification of the superior genotypes and their relationship with bio morphological traits in future breeding programs.

Wheat genotypes reacted differently in the two growing seasons, giving high results in most of the traits that contribute directly to grain yield during crop years (Ristić et al., 2009; Popovic et al. 2020c; Mandić et al., 2020; Đurić et al., 2020; Mirosavljevic et al., 2018; 2019). Similar results were obtained in the research of Milanovic et al. (2019; 2020); Popovic et al., (2020c) and Rakascan et al. (2019a; 2019b; 2021).

The present results confirm the statement of many authors that the traits analyzed, and their correlations are genetically determined but are strongly modified by the nutrient status of the environment and weather conditions (Djekic et al., 2014; Lakic et al., 2018; Rajicic et al., 2020a, 2020b).

Grain yield is one of the most important and complex traits in plant breeding. Knowledge about crop development, growth and dry matter accumulation enables the appropriate selection of genotypes and field technology. Growing season, sowing date, variety and sowing date $\times$ variety interaction had significant influence on crop biomass at anthesis and grain yield of wheat and barley. Dry matter translocation was in positive correlation with dry matter content at anthesis. Dry matter accumulation across growing seasons had a typical sigmoid pattern in every combination of sowing date and variety. These results indicated that during the selection of small grain cereals, it is necessary to develop genotypes characterized by higher leaf number and increased biomass, i.e., genotypes that in optimal sowing dates, have an adjusted phenological development to the agro-ecological conditions of the Panonian plane (Mirosavljevic, 2015). The variety itself cannot give a high yield without the application of all agrotechnical measures, to which we strive for primarily due to the high wheat importance. Wheat yield depended more on sowing time, and the influence of sowing time, variety, and interaction of these two factors on yield were statistically significant. The highest yield was registered $\left(8.87 \mathrm{tha}^{-1}\right)$, while the average yield achieved by this micro experiment was $8.46 \mathrm{t} \mathrm{ha}^{-1}$ (Veliborović 
et al., 2020). Župunski et al. (2021) results indicate the specificity of the years, the locations, and the responses of the varieties to mycobiota associated with winter wheat grain. Swedish scientist MacKey (1966) pointed out that the yield is very relative term, and it is always determined by variety, ecological conditions and level of the sole production. Borojevic and Cupina (1969), by testing yield components in the case of different wheat genotypes, concluded that the greater number of various traits have more decisive role in yield making in the case of various genotypes. It is the result of interaction between traits within one genotype as well as between genotype and environmental factor.

\section{CONCLUSIONS}

The growth trend of alternative fuels has been evident in the world in recent years, thanks to the development of new technologies for processing biowaste into energy sources.

Wheat had a statistically significantly higher average yield of biomass and biogas compared to rye. Based on the analysis of variance, it can be concluded that there are highly significant differences in biomass yield in regard to the genotype $\left(\mathrm{F}_{\mathrm{exp}}=937.75^{* *}\right)$ and years $\left(\mathrm{F}_{\mathrm{exp}}=28.07^{* * *}\right)$ of investigation.

The average biomass yield of the Ilina wheat variety was $2.79 \mathrm{t} \mathrm{ha}^{-1}$, while the rye yield was $2.22 \mathrm{t} \mathrm{ha}^{-1}$. Statistically significantly higher yield was achieved in the second year of the study $2019 / 2020\left(2.56 \mathrm{t} \mathrm{ha}^{-1}\right)$ compared to the first year, 2018/2019 $\left(2.46 \mathrm{t} \mathrm{ha}^{-1}\right)$.

There was a strong positive correlation between biomass yield and biogas yield.

Circular economy is an approach that integrates the economy and the waste management system and is a great chance for the development of each country.

\section{ACKNOWLEDGEMENTS}

This paper is part of the projects, Grant numbers: 451-3-68/202014/200383, 200032 and 200116, financed by the Ministry of Education, Science and Technology Development of Republic of Serbia; and Bilateral Project Republic of Serbia and Montenegro, 2019-2022: Alternative cereals and oil crops as a source of healthcare food and an important raw material for the production of biofuel.

\section{REFERENCES}

Borojevic, S. and Cupina, T. (1969): Components of grain yield in Different Vulgare Wheat Genotypes. Savremena poljoprivreda 1: 3 - 26.

Faostat (2021). FAO Statistical Databases (FAOSTAT). In: FAO Statistical Databases FAOSTAT, Food and Agriculture Organization of the United Nations FAO, http://faostat.fao.org, preuzeto 17.6.2021.

Copeland, J., Turley, D. (2008): National and Regional Supply/Demand Balance for Agricultural Straw in Great Britain. CSL 
Glamoclija, Đ., Jankovic, S., Popovic, V., Filipovic, V., Kuzevski, J., Ugrenovic, V. (2015): Alternative crop species in conventional and organic cultivation system/In Serbia: Alternativne ratarske vrste u konvencionalnom i organskom sistemu gajenja. Belgrade, Serbia. ISBN: 978-86-81689-32-5. P.1-350.

Djekic V., Milovanovic M., Popovic V., Milivojevic J., Staletic M., Jelić M., Perisic, V. (2014): Effects of fertilization on yield and grain quality in winter triticale. Romanian Agriculture Research, 31: 175-183.

Đurić, N., Cvijanović, G., Dozet, G., Rajičić, V., Branković, G., Poštić, D. (2020): Uticaj godine i lokaliteta na prinos zrna i komponente prinosa kod ozime pšenice. Selekcija i semenarstvo, 26 (1): 9-18.

Ikanovc, J., Živanovic, Lj., Popovic, V., Kolaric, Lj., Drazic, G., Jankovic, S., Curovic, M., Pavlovic, S. (2018): Mogućnost većeg korištenja kukuruza kao bioenergenta. Zbornik naučnih radova Instituta PKB Agroekonomik, Beograd, 24, 1-2: 49-58.

Ikanovic J., Popovic V., Pavlovic, S. (2020): Agroecology and soil protection. Book. University of Banja Luka. B\&H, 1-250.

Jankovic, S., Glamoclija, Đ., \& Prodanovic, S. (2017): Energy crops. Monograph, Belgrade, Serbia.

Jankovic, S., Glamoclija, Đ., Ikanovic, J., \& Rakic, S. (2019). Secondary crop products. Monograph, Belgrade. ISBN 978-86-81689-41-7, 1-385

Lakic Z., Glamoclija Dj, Kondic D., Popovic V., Pavlovic S. (2018): Fodder plants and cereals in the function of protecting the soil from degradation. Monograph. Faculty of Agriculture Banja Luka, In Serbian: Krmne biljke i žita u funkciji zaštite zemljišta od degradacije. Monografija. Poljoprivredni fakultet Banja Luka. ISBN 978-99938-93-47, p. 1 - 405.

Ljubicic N., Popovic V., Ciric V., Kostic M., Ivosevic B., Popovic D., Pandzic M., El Musafah Seddiq, Jankovic S. (2021): Multivariate Interaction Analysis of Winter Wheat Grown in Environment of Limited Soil Conditions. Plants-Basel. 10, 3: 604 ;

Mac, Key (1966): The wheat plant as model in adaptation to high productivity under different environments. Savremena poljoprivreda, 11 - 12.

Mandić, D., Pržulj, N., Đurašinović, G., Jovović Z. (2020):Julija: New variety of wheat. Selekcija i semenarstvo. 26 (2): 15-20.

Milanovic, T., Popovic, V., Vuckovic, S., Popovic, S., Rakascan, N. \& Petkovic Z. (2020): Analysis of soybean production and biogas yield to improve ecomarketing and circular economy. Economics of Agriculture, Belgrade, 67 (1): 141156. http://ea.bg.ac.rs Doi: 10.5937/ekoPolj2001141M

Mirosavljevic M. (2015): Variability of phyllochron and dry matter accumulation in different wheat and barley genotypes. PhD thesis. University of Novi Sad Faculty of Agriculture, Novi Sad. 1-138.

Mirosavljevic M., Momcilovic V., Canak P., Trkulja D., Mikic S., Jockovic B., Przulj N. (2018): Grain Filling Variation in Winter Wheat, Barley and Triticale in Pannonian Environments. Cereal Research Communications, 46 (4): 697-706.

Mirosavljevic M., Acin V., Sabados V., Dorotic D. (2019): Variation in Nitrogen Use Efficiency of Winter Wheat. Genetika-Belgrade, 51(3): 1165-1174.

Popovic V., Vidic M., Tatic M., Jaksic S., Kostic M. (2012): The Effect of Cultivar and Year on Yield and Quality Components in Soybean. Ratar. Povrt. 49: 132-139. 
Popovic, D., Vitomir, J., Jokic, M., Arnautovic, I., Vrhovac, D., Barovic, N., Vujinovic, K., Popovic, S. (2020a): Implementation of internal audit in companies intending to operate on the principles of green economy in the Republic of Serbia. Agriculture and Forestry, 66 (2): 93-98.

Popovic V., Vučkovic S., Jovovic Z., Ljubicic N., Kostic M., Rakascan N., GlamoclijaMladenovic M., Ikanovic J. (2020b): Genotype by year interaction effects on soybean morpho-productive traits and biogas production. Genetika, Belgrade, 52, 3: 1055-1073. doi.org/10.2298/GENSR2003055P

Popovic V, Ljubicic N, Kostic M, Radulovic M, Blagojevic D, Ugrenovic V, Popovic D, Ivosevic B (2020c): Genotype x Environment Interaction for Wheat Yield Traits Suitable for Selection in Different Seed Priming Conditions. Plants. 9 (12): 1804.

Rajicic, V., Popovic, V., Perisic, V., Biberdzic, M., Jovovic, Z., Gudzic, N., Mihailovic, V., Colic, V., Djuric, N., Terzic, D. (2020a): Impact of Nitrogen and Phosphorus on Grain Yield in Winter Triticale Grown on Degraded Vertisol. Agronomy, 2020, $10(6): 757$.

Rajicic V, Popovic V, Terzic D, Grcak D, Dugalic M, Mihailovic A, Grcak M, Ugrenovic V (2020b): Impact of Lime and NPK Fertilizers on Yield and Quality of Oats on Pseudogley Soil and their Valorisation. Notulae Botanicae Horti Agrobotanici Cluj-Napoca. 48 (4): 2134-2152.

Rakascan N., Drazic G., Zivanovic Lj., Ikanovic J., Jovovic Z., Bojovic R., Popovic V. (2019a). Effect of genotypes and locations on wheat yield components. Agriculture \& Forestry, 65 (1): 233-242. DOI: 10.17707/AgricultForest.65.1.23

Rakascan, N., Popovic, V., Drazic, G., Ikanovic, J., Popovic, S., Popovic, B., \& Milanovic, T. (2019b). Circular economy in function of obtaining the biogas. XXIII International Eco-Conference ${ }^{\circledR} 2019$ and XIII Environmental Protection of Urban and Suburban, Settlements, $25^{\text {th }}-27^{\text {th }}$ September 2019, Novi Sad, Serbia, 320-329.

Rakascan N., Drazic G., Popovic V., Milovanovic J., Zivanovic Lj., Remikovic-Acimic M., Malanovic T., Ikanovic J. (2021): Effect of digestate from anaerobic digestion on Sorghum bicolor L. production and circular economy. Notulae Botanicae Horti Agrobotanici Cluj-Napoca. 49, 1: 1-13. DOI: 10.15835/nbha12270

Ristic, Z., Momcilovic, I., Bukovnik U., Prasead V., Fu J., De Ridder B., Elthon T., Savic, N., Jelic, M., Knezevic, J., Knezevic, D. (2009): Analiza vremenskih uslova u proizvodnji ozime pšenice na području centralne Šumadije. Zbornik radova, XIV Savetovanje o biotehnologiji sa međunarodnim učešćem, Agronomski fakultet Cacak, 59-65.

RZS (2021):https://publikacije.stat.gov.rs/G2021/Pdf/G202117014.pdf, http://webrzs.stat. gov.rs

Veliborović, M., Kolarić, Lj., Živanović, Lj., Ikanović, J. (2020): Wheat varieties productivity at different sowing dates. Selekcija i semenarstvo, 26 ( 2): 61-68.

Župunski, V.; Jevtić, R.; Lalošević, M.; Mikić, S.; Orbović, B. (2021): The Applicability of Species- and Trichothecene-Specific Primers in Monitoring the Fusarium graminearum Species Complex and Its Impact on the Surveillance of Fusarium Head Blight in Winter Wheat in Serbia. Agronomy, 11, 778. https://doi.org/10.3390/agronomy 11040778 